\title{
PRE-TRIAL DISCLOSURE IN CRIMINAL CASES
}

THE basic purpose of a trial is to ascertain facts. In early times God was assigned the role of fact-finder, and trials consisted of physical ordeals or individual combats to invoke His judgment. ${ }^{1}$ Today, however, disputes are decided by mortals whose verdicts depend on evidence presented by contesting parties. Therefore the objectives of modern trial procedure should be to promote the fullest possible presentation of the facts, minimize opportunities for falsification of evidence, and eliminate the vestiges of trial by combat.

One procedural device which helps to achieve these objectives is compulsory disclosure ${ }^{2}$ of evidence by both sides before trial. By giving each party a chance to dig up new facts which may rebut or explain his opponent's evidence, disclosure reduces the importance of surprise and guesswork. ${ }^{3}$ Under the Federal Rules of Civil Procedure and similar state rules, pre-trial disclosure has become a matter of right, utilized with much success. ${ }^{4}$ In the criminal law, however, its utility has received far less acknowledgment. ${ }^{5}$ Trial by judicial battle, in which concealment is one of the major weapons, remains the modus operandi of the criminal fact-finding process. ${ }^{B}$

\section{Prevailing Law}

To a limited degree, four kinds of disclosure are available in criminal trials. Defendants have some rights to discovery of tangible evidence, inspection of

1. Robertson, Trial by Ordeal, 38 Jurid. Rev. 70 (1926). See also Ploscowe, The Development of Present-Day Criminal Procedures in Europe and America, 48 HARv. I. Rev. 433, 437-41 (1935).

2. The words "disclosure" and "discovery" are used synonymously throughout this Comment to mean disclosure of tangible evidence, testimony, names of witnesses, etc., before trial.

3. Sunderland, foreword to Ragland, Discovery Before Trial iii (1932).

4. See Holtzoff, Instruments of Discovery Under the Federal Rules of Civil Procedure, 41 MrcH. E. Rev. 205 (1942); Pike \& Willis, The Nerv Federal DepositionDiscovery Procedure, 38 CoL. L. REv. 1179, 1436 (1938). On civil discovery prior to the Federal Rules, see Ragland, Discovery Before Trial (1932).

5. This is particularly true of the United States. In England, however, disclosure is an accepted part of criminal procedure. No accused person can be brought to trial without a preliminary hearing at which all of the witnesses give their testimony. The accused is present and may question the witnesses. Depositions are made from each witness' testimony and preserved for trial. The procedure is enforced strictly; irregularities are grounds for quashing a subsequent conviction. See Indictable Offenses Act, 1848, 11 \& 12 VIcr., c. 42, \$\$ 17, 27; Rex v. Gee, 25 Cr. App. R. 198 (1936) ; Rex v. Phillips and Quayle, 26 Crim. App. R. 200 (1938) ; Archibold's Pleading, Evidence and Practice in CRIninal Cases 412-25 (31st ed. 1943).

6. See Orfield, Cruminal Procedure from Arrest to Appeal 321-3 (1947). For a criticism of the so-called "sporting theory of justice," see Pound, Crrminal Justice IN AMrerca 163-4 (1930); Perkins, Absurdities in Criminal Procedure, 11 Iowa I. Rev. 297, 322-35 (1926). 
grand jury minutes, and lists of the government's witnesses. And prosecutors in a few states can obtain notice of certain defenses.

\section{Discovery of Tangible Evidence by Defendants}

Under the common law, defendants are seldom permitted to inspect items of prosecution evidence. Originally, criminal courts were powerless to order discovery $;^{7}$ pre-triai disciosure, it was felt, would subvert criminal justice. Today, however, the power to require production of tangible evidence is generally assumed to exist in the discretion of the trial court. ${ }^{8}$ But in exercising their discretion, most courts have denied discovery on the broad ground that defendants should not be allowed to pry into the prosecution's case. ${ }^{9}$ Occasionally, however, courts have permitted inspection of admissible ${ }^{10}$ weapons, ${ }^{11}$ fingerprints, ${ }^{12}$ memoranda, ${ }^{13}$ or written confessions, ${ }^{14}$ often for unstated reasons, and

7. State v. Jeffries, 117 Kan. 742, 232 Pac. 873 (1925) ; Rex v. Holland, 4 T.R. 691, 100 Eng. Reprints 1248 (1792). The Holland case, which is usually cited as the leading authority for denying power to order discovery, had ceased to be the law of England long before any comparable American cases were decided. See Regina v. Colucci, 3 F. \& F. 104, 176 Eng. Reprints 46 (1861) ; Rex v. Harrie, 6 Car. \& P. 105, 172 Eng. Reprints 1165 (1833).

People ex rel. Lemon v. Supreme Court, 245 N.Y. 24, 156 N.E. 84 (1927), held the trial court powerless to require the prosecutor to disclose notes and memoranda which were inadmissible in evidence. The question whether admissible papers might be ordered disclosed was left unsettled. Accord, State ex rel. Page v. Terte, 324 Mo. 925, 25 S.W. 2d 459 (1930).

For general discussions of discovery of tangible evidence, see People v. Gatti, 167 Misc. 545, 4 N.Y.S. 2d 130 (Ct. Gen. Sess. 1938) ; Notes, 52 ALR 207 (1928); 39 CoL. L. Rev. 287 (1939); 53 Dick. I. Rev. 301 (1949); 41 Harv. L. Rev. 519 (1928); 38 J. Crum. L. \& Crmminology 249 (1947); 20 Tulane L. Rev. 133 (1945) (inspection of written confessions).

8. See e.g., Commonwealth v. Jordan, 207 Mass. 259, 265, 93 N.E. 809, 811 (1911); State v. Di Noi, 59 R.I. 348, 357, 195 A. 497, 501 (1937).

9. E.g., State v. Fitzgerald, 130 Mo. 407, 32 S.W. 1113 (1895) (defendant not permitted to see his own written statement); People v. Skoyec, 183 Misc. 764, 50 N.Y.S. $2 \mathrm{~d} 438$ (Sup. Ct. 1944) (inspection of confession denied); Abdell v. Commonwealth, 173 Va. 458, 2 S.E. $2 d 293$ (1939) (defendant had no right to inspect his notes and diary before trial, although they were later introduced in evidence against him).

10. Where the material sought is inadmissible in evidence the defense has almost no chance of seeing it. See Cramer v. State, 145 Nebr. 88, 95, 15 N.W. 2d 323, 327 (1944); State ex rel. Wagner v. Circuit Court, 60 S. Dak. 115, 119, 244 N.W. 100,101 (1932).

11. Application of Hughes, 181 Misc. 668, 673, 41 N.Y.S. 2d 843, 847 (Sup. Ct. 1943) (gun and bullets).

12. United States v. Rich, 6 Alaska 670 (1922) (piece of glass with fingerprints on it); People v. Terzani, 149 Misc. 818, 269 N.Y. Supp. 620 (County Ct. 1933) (fingerprints on gun).

13. State ex rel. Wagner v. Circuit Court, 60 S. Dak. 115, 244 N.W. 100 (1932) (defendant, indicted for defrauding county by overcharging for construction of bridge, allowed to inspect field notes of county engineer).

14. State v. Haas, 188 Md. 63, 69, 51 A. 2d 647, 849 (1947); People v. Rogas, 158 
sometimes because the object sought formed the basic evidence of the prosecution's charge. ${ }^{15}$ In a few jurisdictions discovery, whete needed to help prepare a defense, has been declared a matter of right. Thus trial court refusals to allow an indicted city treasurer to inspect his seized books, ${ }^{16}$ an alleged murderer to copy his purported confession, ${ }^{17}$ and a man accused of possessing intoxicating liquor to analyze the contents of bottles found in his home ${ }^{18}$ have been reversed on appeal.

Statutes in three jurisdictions allow the accused to move for discovery of certain state evidence. In Florida defendants, upon a showing of good cause, are permitted to participate in state-conducted examinations of ballistics, fingerprints, or stains made by blood, semen, etc.; or to inspect and copy documents, letters, or photographs held by the prosecution. ${ }^{19}$ Inspection of written confessions, however, has been held beyond the scope of the statute. ${ }^{20}$

The 1946 Federal Rules of Criminal Procedure and similar rules in Maryland also permit discovery of evidence. Under Federal Rule 16 defendants may request disclosure of material "obtained from or belonging to the defendant or obtained from others by seizure or process."21 But the reach of Rule 16 is limited. Defendants have been denied inspection of their own written confessions and statements, ${ }^{22}$ statements of accomplices, ${ }^{23}$ and other important documentary evidence. ${ }^{24}$ A recently promulgated Maryland rule

Misc. 567, 287 N.Y. Supp. 1005 (County Ct. 1936) (defendant's psychiatrists allowed to see his confession to help in determining his sanity).

15. United States v. Warren, 53 F. Supp. 435 (D. Conn. 1944) (defendant, charged with mailing package containing threatening letter, allowed to inspect package); People v. Radeloff, 140 Misc. 690, 252 N.Y. Supp. 290 (Ct. Gen. Sess. 1931) (attorney, charged with extortion, permitted to obtain photostatic copies of letter and retainer agreement with client, on which charge was based).

16. People v. Gerold, 265 I11. 448, 470, 107 N.E. 165, 174 (1914).

17. State v. Dorsey, 207 La. $928,958,22$ So. $2 \mathrm{~d} 273,283$, (1945).

18. State v. Naething, 318 Mo. 531, 540, 300 S.W. 829, 831 (1927).

19. Fra. Stat. Ann. $\$ 909.18$ (1943).

20. Williams v. State, 143 Fla. 826, 197 So. 562 (1940).

21. FED. R. CRIMr. P. 16: "Upon motion of a defendant at any time after the filing of the indictment or information, the court may order the attorney for the government to permit the defendant to inspect and copy or photograph designated books, papers, documents or tangible objects, obtained from or belonging to the defendant or obtained from others by seizure or process, upon a showing that the items sought may be material to the preparation of his defense and that the request is reasonable. The order shall specify the time, place and manner of making the inspection and of taking the copies or photographs and may prescribe such terms and conditions as are just."

22. Shores v. United States, 174 F. 2d 838 (8th Cir. 1949); United States v. Chandler, 7 F.R.D. 365 (D. Mass. 1947) ; United States v. Black, 6 F.R.D. 270 (N.D. Ind. 1946).

23. United States v. Brumfield, 85 F. Supp. 696 (W. D. La. 1949).

24. United States v. Rosenberg, 10 F.R.D. 521 (S.D.N.Y. 1950) (defendants in espionage trial not allowed to see sketches of atomic experiment alleged to have been turned over to foreign agents). 
promises to cover more ground than Rule 16. This rule, patterned after Rule 16, contains an additional phrase- "written statements by the defendant" -which presumably includes confessions and incriminating letters. ${ }^{25}$

Federal Rule 17(c) gives defendants greater opportunities for disclosure. This rule provides for subpoenas of documents and objects in a party's possession which either side intends to introduce at the trial. ${ }^{26}$ Unlike most subpoenas, a 17 (c) subpoena may be returnable before trial if the court so directs. ${ }^{27}$ This feature, in effect, turns Rule 17(c) into a discovery provision. And in Bozman Dairy Co. v. United States the Supreme Court allowed a pre-trial subpoena of evidence which the defendant could not have discovered under Rule 16-evidence obtained by the government without the use of seizure or process. ${ }^{28}$ This decision might well enable defendants to obtain disclosure of written confessions under 17(c). A more important consequence of the Bowman case is that defendants in federal courts will have, subject to the court's discretion, access before trial to the government's evidence. For Bowman specifically held that the trial court, if it wants to, may order a pre-trial subpoena of all documents and papers presented to the grand jury or to be offered in evidence at the trial. ${ }^{29}$

\section{Inspection of Grand Jury Minutes}

Advance notice of opposing witnesses' testimony is probably worth more to litigants than discovery of tangible evidence. In criminal trials, however, it is

Prior to the adoption of the Criminal Rules most federal courts opposed disclosure in criminal trials. See, e.g., United States v. Rosenfeld, 57 F. 2d 74 (2d Cir. 1932), cert. denied sub nom. Nachman v. United States, 286 U. S. 556 (1932). A major departure from this policy seemed likely when tentative drafts of the Criminal Rules proposed a broad right to move for discovery of documents, papers or objects "obtained from or belonging to the defendant, or constituting evidence" if the material sought was reasonably necessary for preparing a defense. See Federal Rules of Criminal Procedure, Second Preliminary Draft 94 (1944). In the final draft, however, the discovery rule was changed to its present form.

25. See Rule 5, Maryland Rules of Criminal Procedure, adopted Dec. 6, 1949 by the Maryland Court of Appeals. 71 A. 2d xxviii (advance sheet).

26. Bowman Dairy Co. v. United States, 19 U.S.L. WeEk 4229 (U.S. Apr. 30, 1951).

27. See Dession, The New Federal Rules of Criminal Procedure, 56 Y $\mathrm{ALE}$ L.J. 197, 221 (1947).

28. Bowman Dairy Co. v. United States, stpra note 26, reversing United States v. Bowman Dairy Co., 185 F. 2d 159 (7th Cir. 1950).

29. The subpoena in the Bozwnan case included documents and papers (a) presented to the grand jury, or (b) to be offered in evidence at the trial, or (c) relevant to the charges in the indictment. Documents under (c) were demanded "whether or not they might constitute evidence." The Supreme Court upheld the order as to (a) and (b) but struck it down as to (c) on the ground that (c) was "a catch-all provision, not intended to produce evidentiary materials but merely a fishing expedition to see what may turn up." 19 U.S.L. WEEK 4231 (U.S. Apr. 30, 1951). 
generally available, if at all, only through inspection of grand jury minutes. ${ }^{30}$ And such inspection affords at best only partial disclosure, since the prosecution need not present its entire case to the grand jury. ${ }^{31}$

At least two state statutes give the accused the right to inspect grand jury minutes. ${ }^{32}$ Absent such a statute, a defendant can generally inspect the minutes only to show violation of his constitutional rights, misconduct by the grand jury, or insufficiency of the evidence on which the indictment was based. ${ }^{33}$ New York courts, for example, often allow inspection where insufficiency of evidence is alleged, ${ }^{34}$ while denying it where the defendant appears merely to be seeking information to help prepare his defense. ${ }^{35}$ In the federal courts, however, defendants have generally been denied inspection under any circumstances. ${ }^{36}$

30. Transcripts of testimony at other preliminary inquests are a potential source of the opponent's evidence. But requests for such transcripts are often denied. McAden v. State, 155 Fla. 523, 21 So. $2 d 33$ (1945); Poyner v. Commonwealth, $274 \mathrm{Ky} .813$, 120 S. W. 2 d 649 (1938).

31. The prosecutor need present only enough evidence to satisfy statutory requirements for the bringing of indictments. For a typical statute, see Minn. Stat. Ann. $\S 628.03$ (1946): "The grand jury shall find an indictment when all the evidence taken together is such as, in its judgement, would, if unexplained or uncontradicted, warrant a conviction by a trial jury."

32. Iowa Code Ann. $\$ 772.4$ (1949); Kr. CRIN. Cone $\$ 110$ (Carroll 1948). Most states, however have statutes requiring secrecy of grand jury proceedings. E.g., N. Y. Code Crrs. Proc. $\$ \S 265$, 952-t (1945). See, generally, Note, 37 CoL. L. REv. 315 (1937).

33. For general discussions, see People v. Steinhardt, 47 Misc. 252, 93 N. Y. Supp. 1026 (Sup. Ct. 1905); Kidd, Secrecy vs. Inspection of Grand Jury Minutes, 6 PANEL no. 1 p. 4 (1928). It is sometimes said, however, that defendants have no right whatever to inspect grand jury minutes. See, e.g., Commonwealth v. Galvin, 323 Mass. 205, 211, 80 N.E. 2d 825,830 (1948).

34. People v. Moskowitz, 119 Misc. 837, 196 N. Y. Supp. 634 (County Ct. 1922); People v. Wood, 93 Misc. 701, 157 N. Y. Supp. 541 (Ct. Gen. Sess. 1916) ; People v. Klaw, 53 Misc. 158, 104 N. Y. Supp. 482 (Ct. Gen. Sess. 1907).

35. E.g., People v. Browne, 184 Misc. 764, 54 N. Y. S. 2d 759, (County Ct. 1945); People v. Keppler, 25 N. Y. S. 2d 804 (Sup. Ct. 1941). But cf. People v. Kresel, 142 Misc. 88, 254 N. Y. Supp. 193 (Sup. Ct. 1931) (Kresel had testified at a grand jury investigation which resulted in the indictment of another man. At the trial, Kresel allegedly contradicted his previous testimony; he was thereupon indicted for perjury. The court before which Kresel was to be tried held that he was entitled to inspect the very lengthy testimony he gave at the original grand jury hearing for the explicit purpose of preparing his defense).

36. E.g., United States v. Garsson, 291 Fed. 646, 649 (S.D.N.Y. 1923) (per L. Hand, J.: "[Inspection] is said to lie in discretion, and perhaps it does, but no judge of this court has granted it, and I hope none ever will.") ; United States v. Morse, 292 Fed. 273, 278 (S.D.N.Y. 1922) (per A.N. Hand, J.: "[I]t has, I think, generally been regarded in this district as impossible for a defendant to obtain an order for examination of the minutes, as may be done in the New York State courts") ; United States v. National Wholesale Druggists' Ass'n., 61 F. Supp. 590 (D.N.J. 1945). But see United States v. Socony-Vacuum Oil Co., 310 U.S. 150, 233-4 (1940) : "Grand jury testimony is ordinarily confidential . . . But after the grand jury's functions are ended, disclosure is wholly proper where the ends of justice require it." 


\section{Names of Prosecution Witnesses}

An important object of disclosure is to enable each side to know the names of opposition witnesses. ${ }^{37}$ Although the common law afforded no such right, ${ }^{33}$ in most states defendants are now entitled, by case law or by statute, to a pretrial list of the names and addresses of prosecution witnesses. ${ }^{39}$ Usually the list need include only witnesses who testified before the grand jury..$^{40}$ More rarely, the requirement covers all witnesses known to the prosecutor or all he intends to produce at the trial. ${ }^{41}$ An old federal statute gives defendants in capital cases the right to a list of witnesses to be produced at trial. ${ }^{42}$ But in line with their general policy against disclosure, the federal courts have refused to extend this right to other categories of defendants. ${ }^{43}$

Even a list requirement covering all witnesses which the prosecution intends to produce at trial does not necessarily prevent the production of new witnesses. Generally the prosecutor can produce unlisted witnesses if he did not know of them when he submitted his list to the defendant. ${ }^{44}$ In addition, witnesses can usually be called in rebuttal without prior notice. ${ }^{45}$

37. For judicial opinions to this effect, see State ex rel. Porter v. District Court, 220 P. 2d 1035, 1042 (Mont. 1950) ; Leahy v. State, 111 Tex. Crim. 570, 585-9, 13 S.W. $2 d 874,881-2$ (1928).

38. State v. Daspit, 129 La. 752, 56 So. 661 (1911); Cornell v. State, 104 Wis. 527, 539, 80 N.W. 745, 749 (1899).

39. The rules of all American jurisdictions are set forth and analyzed in 6 WIGMore, EVIDENCE $\$ \$ 1850-5$ (3d ed. 1940).

In Washington the witness list statute, which applies only to prosecutions by information, also requires the defendant to give the prosecuting attorney a list of defense witnesses to be called at the trial. The defendant must file his list five days after receiving the prosecutor's list. WasH. REv. Stat. \$2050 (Remington 1932).

40. E.g., Okla. Stat. AnN. tit. 22, § 384 (1938); S. Dak. Cone $\$ 34.1233$ (1939).

41. E.g., ARIz. CoDE ANN. $\$ 44759$ (1939) (the statute provides, however, that "[n]o continuance shall be allowed because of failure to endorse any of said names"); Colo. Stat. AnN. c. 48 \$455 (1935); Iowa Code Ans. \$769.4 (1949). The Colorado and Iowa statutes apply only to prosecutions by information. In the latter state the defendant is also entitled to a minute of the testimony of each witness on the list.

42. 18 U.S.C. $\$ 3432$ (1946).

43. Moore v. Aderhold, 108 F. $2 d 729$ (10th Cir. 1939) ; Jones v. United States, 162 Fed. 417 (9th Cir. 1908), cert. denied, 212 U.S. 576 (1908); United States v. Oley, 21 F. Supp. 281 (E.D.N.Y. 1937). The federal rule, under such a construction, is somewhat inconsistent. If disclosure of witnesses is permissible in civil cases but not in criminal cases because the fear of prison makes defendants likely to tamper with witnesses, then tampering should be most likely in those cases involving the death penalty.

For a strict interpretation of a state witness statute, see State ex rel. Porter v. District Court, 220 P. 2 d 1035, 1041-3 (Mont. 1950).

44. People v. Weisberg, 396 Ill. 412, 71 N.E. 2d 671, cert. denied. 331 U.S. 826 (1947) ; State v. Cook, 30 Kan. 82, 1 Pac. 32 (1883). Some courts allow the prosecutor to call unlisted witnesses at the trial even if he did know of them at the time he submitted his list to the defendant. State v. McDonald, 51 Mont. 1, 149 Pac. 279 (1915) (although prosecutor violated statutory command by neglecting, deliberately or through ignorance, to endorse some witnesses, defendant was denied a new trial).

45. E.g., Schreiner v. People, 95 Colo. 392, 36 P. 2 d 764 (1934). 


\section{Pleading Affirmative Defenses}

A form of disclosure especially important to prosecutors is advance notice of the theory of the defendant's case, While the state must reveal in the indictment or information the nature of its charge against an accused, under the common law the defendant need give no notice of his defense in his plea of "not guilty." Ordinarily such defenses as entrapment, alibi, self-defense and insanity may be offered at the trial without prior warning. ${ }^{46}$

A number of states have changed the common law rule by enacting statutes requiring defendants to plead specially defenses of alibi or insanity. ${ }^{47}$ If the defense is not pleaded the court may exclude evidence tending to prove it. ${ }^{48}$ The statutes have been construed, however, to permit the defendant to establish any defense at any time by his own testimony. ${ }^{49}$ The Federal Rules of Criminal Procedure contain no provision for disclosure of defenses. An alibi rule was proposed in the tentative drafts, but was not promulgated by the Supreme Court. ${ }^{50}$

46. See, e.g., Romero v. Squier, 133 F. 2d 528, 532 (9th Cir. 1943) (entrapment); Shields v. State, 221 Ala. 321, 128 So. 786 (1930) (self-defense); Leonard v. State, 17 Ariz. 293, 299, 151 Pac. 947, 949 (1915) (alibi); James v. State, 110 Ark. 170, 171, 160 S.W. 1090 (1913) (statute of limitations); People v. Joyce, 233 N.Y. 61, 70, 134 N.E. 836,840 (1922) (insanity).

47. On special pleas of affirmative defenses in criminal cases, see, generally, Comment, 38 Y ALE L.J. 650 (1929).

On alibi statutes, see Federal Rules of Crrarrnal Procedure, Second Preliminary Draft 81-9 (1944); Millar, The Statutory Notice of Alibi, 24 J. CRIMr. L. \& CRIMinology 849 (1934); Notes, 10 Ford. L. Rev. 305 (1941); J. CrIM. L. \& CrinsINOLOGY 629 (1940); 21 VA. L. REv. 940 (1935).

On insanity statutes, see State v. Wallace, 170 Oreg. 60 , 91-105, 131 P. 2d 222, 234-40 (1942).

In Scotland, a statute has long required the pleading of all affirmative defenses. 50 \& 51 VICr. c. 35, \&36 (1887). In England the effectiveness of surprise alibi defenses has been limited by the courts' practice of making unfavorable comments to the jury on the defendants' failure to reveal his defense earlier. See The Defense of Alibi, 179 L. T. 212 (1935) ; Note, 26 J. Crim. L. \& Crminology 454 (1935).

48. E.g., Ind. Stat. ANN. \$9-1631 (Burns 1933) (if defendant desires to make an alibi defense, he must give notice; he can then demand that the prosecutor inform him of the exact time and place of the alleged offense) ; Minn. Stat. ANn. $\$ 630.14$ (1946) (upon application of prosecutor, defendant must file notice of alibi, stating where he was at the time of the crime; if he fails to file the notice, evidence of alibi may be excluded); Wask. Rev. Srat. $\$ 2174$ (Remington 1932) (if defendant desires to plead insanity, he must so state when he pleads to the indictment); Wrs. Stat. $\$ 355.07$ (1949) (same as Minnesota, except that defendant must give notice without being asked for it).

49. People v. Rakiec, 289 N.Y. 306, 45 N.E. $2 d 812$ (1942); Note, 15 St. JoHN's L. Rev. 304 (1941).

Alibi statutes are apparently invulnerable to constitutional objections. People v. Schade, 161 Misc. 212, 292 N. Y. Supp. 612 (County Ct., Queens County 1936) ; See State v. Thayer, 124 Ohio 1, 4, 176 N.E. 656,657 (1931).

50. Federal Rules of Criminal Procedure, Second Preliminary Draft 80 (1944). 


\section{The Case For and Against Disclosure}

\section{Objections to Disclosure}

Perjury and Tampering with Witnesses. The major argument against criminal discovery is that instead of aiding it would deter accurate fact-finding. Advance disclosure, it is said, gives defendants the opportunity to falsify and suppress evidence. The criminal, if he knows the case against him, will procure perjured testimony to establish a false defense. ${ }^{51}$ In addition, the argument continues, the accused, if informed of adverse witnesses' testimony, may cajole, bribe, or frighten them into changing their stories or having "memory lapses." 52 And such misuse of discovery is more likely in criminal than in civil cases, because litigants have a much higher stake in the outcome. ${ }^{53}$

A similar objection is made to forcing defendants to reveal the names of their witnesses. According to one writer, intimidation by prosecutors is so effective that the result of such disclosure "will be that the defendant, guilty or innocent, will have no witnesses at the trial, unless it happens that he was visiting the archbishop on the night of the crime." 54

While subornation of perjury and tampering with witnesses are a real problem, they can occur almost as easily without a change in the prevailing law of disclosure. The guilty defendant, necessarily acquainted with the details of the crime which the state must prove, can fabricate a defense accordingly. ${ }^{65}$ In addition, in most jurisdictions he is already furnished with a list of prosecution witnesses, ${ }^{56}$ whom he can tamper with as he pleases. Only the innocent have no

51. See State v. Rhoads, 81 Ohio St. 397, 423-4, 91 N.E. 186, 192 (1910); Commonwealth v. Mead, 12 Gray 167,170 (Mass. 1858) ("The reasons on which the sanction of secrecy which the common law gives to proceedings before grand juries is founded are said in the books to be threefold ... A second is that perjury and subornation of perjury may be prevented by withholding the knowledge of facts testified to before the grand jury, which if known, it would be for the interest of the accused or their confederates to attempt to disprove by procuring false testimony.").

According to experts, perjury is already "omnipresent" in our courts. Boston, Drastic Change In Law Necessary To Curb Perjury In Our Courts, 13 Panel no. 1, p. 6 (1935); Hopkins, The Lawyer's Duty' Tozward A Guilty Client, 9 PANeL 48 (1931). See also Greenberg, Perjury is YOUR Concern, 24 Panel 3 (1950); Hibschman, "You Do Solemnly Swear!" Or That Perjury Problem, 24 J. CrIMr. L. \& CRIMrnology 901 (1934).

52. See Snith, Grand Jury IVitnesses, 6 PANeL no. 9, p. 8 (1928); Note, 21 West VA. L. Q. 301 (1935) ; Elpern, Disintegration of Justice by Tampering with IVitnesses and Testimony, 6 PaneL no. 9, p. 3 (1928).

53. A further argument against disclosure is that it might keep witnesses from coming forward with information during investigations of crime. Sce Commonwealth v. Mead, 12 Gray 167, 170 (Mass. 1858); People v. Di Carlo, 161 Misc. 484, 485-6, 292 N.Y. Supp. 252, 254 (Sup. Ct. 1936).

54. Stewart, Comments on Federal Rules of Criminal Procedure, 8 JoHn Manshald L.Q. 296, 300 (1943).

55. Seemingly, the only way to keep a guilty defendant from preparing a false defense is to conceal from him the fact that he is charged with crime.

56. See note 39 supra. For the same reason, the danger that witnesses would be afraid to give information, note 53 supra, is almost as great under present law. 
inkling of what facts the government must prove or what the listed witnesses will probably say; they are the real beneficiaries of disclosure.

Moreover, the dangers to accurate fact-finding apply mainly to testimony of witnesses, not to inspection of tangible evidence. It is not easy to tamper with documents or inanimate objects, or to refute them by perjury. And even where witnesses are involved, the fear of perjury is perhaps overstated. Perjury is an ancient bugaboo, trotted out periodically to block procedural reform. Interested parties were once disqualified from testifying, largely because everyone thought they would lie. Disqualification ended when the potential evils of perjury were finally felt to be outweighed by the manifest injustice of excluding essential evidence. ${ }^{57}$ Denial of disclosure to forestall false defenses is perhaps equally unwise.

Prosecution at a Disadvantage. A further objection to disclosure begins with the premise that criminal procedure is overweighted in favor of the accused, and concludes that it would be unjust to the public to give defendants the additional help of discovery. ${ }^{58}$ In civil litigation, the argument runs, parties are on an equal footing, but in criminal trials such rules as the presumption of innocence give the accused all the advantages. And as one court put it, "[i]n these days criminals are both skilled and cunning, and it is a contest between the people and the criminals for the mastery." their evidence in civil trials, it is said that this element of reciprocity is lacking in criminal cases because of the accused's privilege against self-incrimination. ${ }^{60}$

57. See 2 Wigmore, Evidence \$§ 575-7 (3d ed. 1940).

58. See L. Fand J. in United States v. Garsson, 291 Fed. 646, 649 (S.D.N.Y. 1923) : "Under our criminal procedure the accused has every advantage. While the prosecution is held rigidly to the charge, he need not disclose the barest outline of his defense. He is immune from question or comment on his silence; he cannot be convicted when there is the least fair doubt in the minds of any one of the twelve. Why in addition he should in advance have the whole evidence against him to pick over at his leisure, and make his defense, fairly or foully, I have never been able to see.... Our dangers do not lie in too little tenderness to the accused. Our procedure has always been haunted by the ghost of the innocent man convicted. It is an unreal dream. What we need to fear is the archaic formalism and the watery sentiment that obstructs, delays, and defeats the prosecution of crime." For an even more extreme viewpoint on the part of a federal judge, see Yankwich, Concealment or Revealment, 3 F.R.D. 209, 210-11 (1943).

59. State v. Rhoads, 81 Ohio St. 397, 424-5, 91 N.E. 186, 192 (1910).

60. See State v. Bunk, 63 A. 2d 842, 844 (New Jersey County Court, 1949). ("The element of reciprocity is present in the conduct of civil causes. Each party may examine the other, force disclosure of material evidence and thus reduce to a minimum the element of surprise or chance in the trial. In criminal cases no such reciprocity is possible. The State could not examine the defendant before trial without his consent, nor could any rule of court . . f force . . . such examination.") ; State v. Rhoads, supra note 59. ("The state cannot compel the prisoner at the bar to submit his private papers or memoranda to the state for use or even examination... Then, why should the accused be allowed to rummage through the private papers of the prosecuting attorney? Neither the sublime teachings of the Golden Rule to which we have been referred, nor the supposed sense of fair play, can be so perverted as to sanction the demands allowed in this case [inspection of grand jury minutes]."). 
Fairness therefore dictates that the defendant be precluded from "fishing" into the people's case. ${ }^{61}$

This argument is based on several questionable assumptions. First, the assertion that the accused always has the upper hand is not necessarily true. Many defendants suffer the handicaps of low intelligence, lack of funds, and inadequate counsel; they face an opponent with potentially unlimited resources. ${ }^{62}$ Second, a fair degree of reciprocity in disclosure is attainable. Defendants may be required to give notice of an alibi or insanity defense, and to reveal the names of their witnesses. ${ }^{63}$ Third, talk of "disadvantage" to the government assumes that criminal trials are contests in which the state's sole interest is to win cases. Actually, criminal procedure has two objectives-to convict the guilty and acquit the innocent ${ }^{64}$-and the prosecutor, as a public official, should not pursue one to the neglect of the other. Indeed, it has been said that the substantive law should be designed for criminals, the procedural law for innocent persons. ${ }^{65}$

Defendant at a Disadvantage. Unfair disadvantage may also be advanced as an argument against requiring defendants to serve notice of special defenses or submit to other discovery. The argument is three-fold. For one thing, the

61. See People v. Skoyec, 183 Misc. 764, 766, 50 N.Y.S. $2 d$ 438, 440 (Sup. Ct. 1944).

62. See Stewart, Federal Rules of Criminal Procedure 155 (1945): [After quoting Judge Yankwich, supra note 58] "This view must be shared by the Advisory Committee [on the Federal Rules of Criminal Procedure]. I wonder where they obtain their information that it is one sided in favor of a defendant when everyone of experience in the practice knows that the exact opposite is the truth. How do they account for the conviction of almost everyone indicted in federal courts if they believe that the government has anything but the best of it? I don't think that the framers of our Constitution believed that a defendant should be required to 'meet some element of surprise.' We do know, however, that such is the present practice and no effort was made by the rule makers to correct the evils of federal practice."

63. See page 632 supra.

64. Professor Hall suggests that the basic dilemma of criminal procedure "consists in the fact that the easier it is made to prove guilt, the more difficult does it become to establish innoncence." Hall, Objectives of Federal Criminal Procedural Revision, 51 Y ALE L.J. 723, 728 (1942).

65. Id. at 730. Hall sums up his views thus: "It may be wise to place certain restrictions on the present mode of criminal defense but it is obviously fallacious to pretend that the necessity or wisdom results because the pendulum has swung too far already in favor of the accused. We know that under present safeguards, innocent persons are convicted, and the recent federal provision for compensation implies that their number is not negligible. Anyone with actual experience in the administration of criminal law realizes that in the vast majority of cases the handicaps of fortune and intelligence are so great as to make 'equality' of the parties hardly more than a humbug. The professional criminal undoubtedly has many advantages but they result from his greater knowledge, financial and political support, as well as from deficiencies in the substantive law.... Certainly any revision in criminal procedure constructed with professional offenders particularly in mind, or on the supposition that the rogues have too many chances of escape' because of the 18th and 19th century progress in safeguards, would result in a ritual whose efficiency would be equalled only by its terror." Ibid. See, generally, Borchard, Convicting the InNocent (1932). 
prosecution, with its superior resources for investigation, scientific tests, and legal preparation, is better able than the ordinary defendant to make use of disclosure. $^{\text {.6 }}$ Furthermore, to require notice of special defenses would revive the injustices of the old rules of pleading. ${ }^{67}$ Failure to plead a defense might deprive an accused of the right to offer it-a harsh consequence to ignorant defendants whose counsel may be careless or overworked. ${ }^{68}$ Finally, compelling disclosure by defendants is said to resemble too closely European inquisitorial methods. ${ }^{69}$ Continental investigating magistrates can subject the accused to exhaustive questioning. ${ }^{70}$ But Anglo-American law allows the defendant to remain silent and challenge the prosecution to prove him guilty. ${ }^{\mathbf{T 1}}$

66. For a suggestion that disclosure of alibi defenses is unjustifiable unless there is mutual disclosure, see Dession, The New Federal Rules of Criminal Procedure, 56 Y YLE L.J. 197, 215-16 (1947).

67. Formerly it was easy for civil litigants to lose their rights because of slight errors or omissions in pleading. See, e.g., Frosh v. Sears, Roebuck \& Co., 124 Conn. 300, 199 Atl. 646 (1938); Voccia v. Pleasure Boat Co., 239 App. Div. 165, 267 N. Y. Supp. 240 (1st Dep't 1933).

68. State v. Wallace, 170 Ore. 60,131 P. 2 d 222 (1942), illustrates how requiring notice of special defenses may cause seeming injustice. Defendant, a swamper in a Chinese gambling establishment, was accused of murder. His court-appointed lawyers had him examined by a psychiatrist, who pronounced him sane. Hence the required notice of the defense of insanity was not given. But at the beginning of the trial, the prosecutor, in his opening statement, revealed facts about the crime which indicated that defendant had been insane at the time he committed the murder. The defense attorneys, claiming that this information was new to them, asked the court for permission to give notice of an insanity defense. The request was denied. Subsequently, although the prosecution in proving its case presented considerable evidence of the defendant's irrational behavior, the court refused to submit the issue of insanity to the jury. Defendant was convicted and sentenced to death. On appeal, the conviction was affirmed by a bare majority. The dissenting opinion stated: "[T]he writer can come to no other conclusion than that defendant was denied the right given to him by substantive law which entitles him to be fully heard upon the only defense he had. The writer thinks that, especially in a capital case, procedural law should not be permitted to prevent substantive law from being available to the defendant." 170 Ore. 136-8, 131 P. 2d 251-2.

69. See Fee, Pre-Trials in Criminal Cases, 4 F.R.D. 338 (1946).

70. See, generally, Ploscowe, The Investigating Magistrate (Juge D'Instruction) In European Criminal Procedure, 33 MicH. L. Rev. 1010 (1935). For a description of the French preliminary hearing, at which the accused and other witnesses are questioned in secret, see Keedy, The Preliminary Investigation of Crime In France, 88 U. of PA. L. REv. 692, 705-23 (1940). American criticisms of French procedure are discussed, and the French system partially defended, in Hogg, French Criminal Procedure, 23 Can. B. Rev. 846 (1945).

71. On the historical origins of the differences between inquisitorial methods and Anglo-American accusatorial procedures, see Howard, Some Characteristics and Tendencies of English Criminal Justice, 15 Minv. L. Rev. 525 (1931). The historical development is given in Ullman, Some Medieval Principles of Criminal Procedure, 59 JUnu. REv. 1 (1947). The Anglo-American system has been severely criticized for unduly protecting guilty defendants. See Perkins, supra note 6; Dean, Advance Specifications of Defense in Criminal Cases, 20 A.B.A.J. 435-6 (1934). 
None of these fears is entirely justified. While prosecutors have greater resources at their disposal than most defendants, their advantage is partly offset by the safeguards afforded the accused. ${ }^{\mathbf{7 2}}$ The danger of inadvertant mistakes in pleading can be avoided by relying instead on full examination of witnesses before trial as the mechanism of disclosure. ${ }^{73}$ And discovery can hardly result in inquisitions; the defendant, by invoking his constitutional privilege, can refuse to answer any questions or to produce incriminating evidence. ${ }^{\mathbf{7 4}}$

\section{Arguments for Discovery}

Preparation for Trial. The principal argument for broader pre-trial disclosure is that it is necessary to help the defense prepare its case. ${ }^{75}$ Since modern indictments are uninformative, ${ }^{76}$ surprise is quite possible. Surprise can easily result in injustice ; for cross-examination, impeachment, and rebuttal depend for their effectiveness on careful investigation and preparation.77 These weapons are virtually useless to an attorney faced at trial with unexpected evidence from a previously unknown hostile witness. ${ }^{78}$ In such situations, brief

72. It is hard to reconcile the picture of the helpless defendant with the opposing view that the accused has every advantage over the government. See page 634 supra. Perhaps the true situation lies somewhere between these two extremes.

73. See Rule 3, page 642 infra.

74. Alibi statutes, for example, probably do not violate the Fifth Amendment; they do not compel the defendant to be a witness against himself or to give evidence against himself. See Robinson, The Proposed Federal Rules of Criminal Procedure, 27 J. Am. Jud. Soc'y. 38, 45-6 (1943). On the privilege against self-incrimination, see, generally 8 WIGMORE, EVIDENCE $\$ 2250$ et seq.

75. See United States v. Rich, 6 Alaska 670-1 (1922).

76. Discovery is a necessary complement to a system of simple notice pleading, in which the complaint (or indictment) is too brief and general to furnish an adequate basis for trial preparation. See Ragland, Discovery Before Trial 261-3 (1932). A function somewhat similar to discovery is performed by the bill of particulars and the prosecutor's opening statement. That intentional failure of the prosecutor to outline his case in the opening statement may be grounds for reversing a conviction, see Note, 5 TEMrple L. Q. 469 (1931).

Some prosecution evidence may be disclosed at a preliminary examination before a magistrate immediately after arrest. But this is an inadequate substitute for other forms of disclosure. Preliminary examinations are not mandatory. And where they are held, they may reveal only fragments of the prosecution's case. See OrfIELd, CrIMIinal Procedure from Arrest to Appear 279 (1947).

77. Cross-examination must be planned carefully in advance. Adverse witnesses should be interviewed, their backgrounds investigated, and evidence likely to prove self-contradiction or perjury collected. See Busch, Law and Tactics In JuRy Trials 460-6 (1949); Cornelius, Trtal Tactics 248-55 (1932).

78. In Keser v. Commonwealth, $195 \mathrm{Ky} .809,243$ S.W. 1020 (1922), defendant, accused of possessing intoxicating liquor, was surprised at the trial by the testimony of one Boggs, who said he had seen defendant throwing whiskey out of an upstairs window while officers were searching the premises below. Upon conviction, defendant appealed, claiming he could bring witnesses to contradict Boggs, but had not been able to round them up in time to rebut the unexpected testimony. The court, holding that defendant had been unfairly surprised, ordered a new trial. 
continuances are of little aid, and subsequent motions for a new trial on the ground of unfair surprise are seldom granted. ${ }^{79}$

The need for discovery is underlined by the growing intricacy of issues in criminal trials. Such up-to-date crimes as financial fraud, conspiracy, and antitrust violation necessitate elaborate investigation and research before trial. ${ }^{80}$ And today even an old-fashioned murder case may involve complicated, scientific evidence. ${ }^{81}$ Participation in state-conducted tests on bloodstains, fingerprints, or ballistics, for example, may be a life-and-death matter to a defendant. ${ }^{82}$

Discovery is also necessary to help the prosecution prepare for trial. If the defendant is allowed to conceal his hand, he may surprise the prosecution with an alibi or insanity defense. ${ }^{83}$ When an unexpected defense is kept secret until near the end of the trial, the state has no time to investigate the story or the witnesses. Criminals may escape conviction with false alibis which the state, if forewarned, might have refuted. ${ }^{84}$

To the extent that lack of disclosure by either side causes unpreparedness or surprise, it makes trials resemble the old wager of battle. The modern combatants are the lawyers, and their weapons are secrecy, maneuver, and sudden revelation. ${ }^{85}$ Procedure which puts a premium on clever tactics is not the best way to determine truth.

79. E.g., Lewis v. Commonwealth, $190 \mathrm{Ky} .160,227$ S.W. 149 (1920); see Hagan v. Commonwealth, 179 Ky. 201, 205-6, 200 S.W. 336, 337-8 (1918). But cf. State v. Price, 100 W. Va. 699, 131 S.E. 710 (1926), reversing a conviction because the prosecution introduced unexpected evidence.

80. For the complex type of proof required in antitrust cases, and resultant problems, see Dession, The Trial of Economic and Technological Issues of Fact, 58 YALE L.J. 1019, 1242 (1949). In such cases the defendant's rights to disclosure are entirely different depending on whether the government chooses to bring a civil or a criminal action. If it brings a civil suit, the defendant can invoke the extensive provisions of the Federal Rules of Civil Procedure; but if it brings a criminal action, the defendant can obtain virtually no disclosure under the Criminal Rules.

81. See O'Hara \& Osterburg, An Introduction to Cruntinalistics (1949).

82. See Note, 41 J. CRnS. L. \& CRMrrnology 64 (1950), advocating a statute allowing defendants to inspect the results of state-conducted tests and experiments.

83. See Esch, Ohio's New "Alibi Defense" Law, 9 Panel 42 (1931).

84. See Dean, supra note 71, at 436; Freeman, Should the Defendant in a Criminal Case Fite a Written Pleading Outlining His Defense, 8 Mrrs. L. REv. 357 (1924); Millar, The Modernization of Criminal Procedure, 9 J. Arr. Jud. Soc'y. 135, 139-40 (1925).

Alibi statutes, now fairly common, see note 47 supra, have reportedly been successful in reducing the number of acquittals on alibi defenses. See Esch, supra note 83; Toy, Michigan Law on Alibi and Insanity Defenses Reduces Perjury, 9 PANEL 52 (1931). The Scottish affirmative defense law, note 47 supra, is also reported to have improved the administration of justice. See Note, English and Scottish Criminal Procedure-Some Comparisons, 102 Just. P. 644, 645 (1938).

85. See Berge, The Proposed Federal Rules of Criminal Procedure, $42 \mathrm{MrcH}$. L. REv. 353, 366 (1943): "Criminal trials should not be regarded as sporting games in which the adversaries have secret plays which they may properly conceal until some dramatic moment. Entertainment for participants or spectators is not the goal of a criminal trial." 
Preservation of Testimony. Discovery is more than an aid to trial preparation. When linked to a deposition procedure, it is useful in preserving accurate testimony. ${ }^{86}$ If witnesses are interviewed before trial, and their statements turned into depositions, their knowledge can be recorded while their recollections are fresh and presumably most correct. ${ }^{87}$ Trials may be long postponed, and inaccurate or false testimony is likely when the witness, having forgotten his actual observations, must "revive" them with the aid or connivance of one of the parties. ${ }^{88}$ But once a witness' testimony is down on paper, his story is harder to change: depositions can always be used to impeach perjurers and refresh the recollection of the forgetful..$^{80}$

\section{Summary}

The main argument for discovery is that it may aid in getting at truth and in reducing the combat element in trials. Opposition to discovery, on the other hand, is largely based on the belief that it will make falsification of evidence easy. But since the opportunity for perjury exists anyway, and since disclosure is designed to combat perjury affirmatively by aiding in its exposure, the probable advantages of disclosure outweigh its potential abuses. Discovery procedures for criminal trials should therefore be expanded.

86. See Ragland, Discovery Before Trial 11-24, 124-5, 241-6 (1932).

87. This procedure is a vital element of discovery in the Federal Rules of Civil Procedure. On the federal deposition procedure in practice, see Comment, 59 YALE L.J. 117 (1949).

In federal criminal proceedings, depositions may be taken only under the circumstances set forth in Rule 15 (a), FED. R. CRIMr. P.: "If it appears that a prospective witness may be unable to attend or prevented from attending a trial or hearing, that his testimony is material and that it is necessary to take his deposition in order to prevent a failure of justice, the court at any time after the filing of an indictment or information may upon motion of a defendant and notice to the parties order that his testimony be taken by deposition and that any designated books, papers, documents or tangible objects, not privileged, be produced at the same time and place."

88. See Alexander, Uproot Perjury by Prompt Examination of Witnesses, 7 Panel no. 1 p. 2 (1929); Note, To Combat Perjury and Reduce Legal Delays, id. at 4.

89. The Federal Rules of Criminal Procedure provide as follows for the use of depositions at trial: "At the trial or upon any hearing, a part or all of a deposition, so far as otherwise admissible under the rules of evidence, may be used if it appears: That the witness is dead; or that the witness is out of the United States, unless it appears that the absence of the witness was procured by the party offering the deposition; or that the witness is unable to attend because of sickness or infirmity; or that the party offering the deposition has been unable to procure the attendance of the witness by subpoena. Any deposition may also be used by any party for the purpose of contradicting or impeaching the testimony of the deponent as a witness. If only a part of a deposition is offered in evidence by a party, an adverse party may require him to offer all of it which is relevant to the part offered and any party may offer other parts." FEd. R. CRnM. P. 15 (e). 
In exploring the possibilities for further disclosure, the Federal Rules of Civil Procedure serve as a useful guide. ${ }^{90}$ Of the various devices provided in the Civil Rules, at least four-inspection of evidence, physical and mental examinations, examination of witnesses before trial, and pre-trial conferencesare in varying degrees adaptable to criminal procedure. The following rules are proposed as a skeleton draft of a criminal disclosure statute. ${ }^{01}$

\section{Proposed Rules}

\section{Rule 1: Inspection of Tangible Evidence}

At least twenty days before trial, or earlier if the court so orders, each party shall produce at a time and place designated by the court all documents, papers or things which the party intends to introduce in evidence. Thereupon any party shall, in the presence of a person designated by the court, be permitted to inspect or copy any such documents, papers or things. ${ }^{92}$ If the evidence relates to scientific tests or experiments, the opposing party shall also be permitted to be present during the tests and to inspect the results thereof. The court shall exclude any evidence not presented for inspection or copying pursuant to this Rule, unless good cause is shown for failure to comply..$^{93}$ In the latter case the opposing party shall be entitled to a continuance during which it may inspect or copy the evidence in the manner provided above.

Comment. This Rule extends radically both the prosecution's and the defendant's opportunities for getting disclosure, by compelling reciprocal production of all tangible evidence before trial.

Since this Rule is limited to the production of evidence which will be offered at the trial, it cannot be criticized for permitting "fishing expeditions" into the opposition's case. For the same reason, it does not violate the defendant's privilege against self-incrimination. He need reveal only what he intends to produce anyway in his own defense.

The Rule goes beyond the Florida statute by giving defendants an absolute right to participate in scientific tests and experiments. ${ }^{94}$ It does the same for the right to inspect confessions and incriminating letters, omitted from Federal Rule 16, but included in Maryland, ${ }^{95}$ since such documents will normally be offered in evidence by the prosecution.

90. At least one federal district judge has suggested that the spirit of the Civil Discovery Rules be carried over into criminal procedure. Freed, The Rules of Criminal Procedure: An Appraisal Based on a Year's Experience, 33 A.B.A.J. 1010, 1012 (1947).

91. No attempt has been made to include all of the details that would be necessary in a carefully drafted statute. Instead, references are given to comparable provisions of the Federal Civil Rules, the details of which should in most instances be suitable for criminal procedure.

92. See FED. R. CIV. P. 34.

93. See FED. R. CIv. P. 37 (b) (2) (ii).

94. See note 19 supra.

95 See note 29 supra. 


\section{Rule 2: Inspection of Books, Papers, and Objects by Defendant}

Upon motion of the defendant at any time after the filing of an indictment or information, the court may, upon a showing of good cause, order the prosecution to produce for inspection or copying by the defendant designated books, documents, papers or things:

(a) Taken from the defendant by the prosecution;

(b) Taken from others by seizure or process; or

(c) Necessary to the preparation of the defendant's case;

regardless of whether the prosecution intends to introduce in evidence such books, documents, papers or things, and regardless of whether they are admissible in evidence.

Comment. This Rule covers disclosure of certain objects in the prosecutor's possession which he may not even introduce in evidence. The purpose of (a) and (b) is to make available objects which the defendant would ordinarily have been able to inspect had it not been for government seizure. ${ }^{.6}$ These subsections incorporate the substance of Federal Rule 16.97 Material not included in (a) and (b), but nevertheless necessary to trial preparation, is available in the court's discretion under $(c) .98$

Rule 2 is restricted to prosecution disclosure to obviate constitutional objections under the privilege against self-incrimination. ${ }^{90}$ The Rule includes checks not present in Rule 1. To police unreasonable and harassing requests,

96. See FEd. R. CRIMr. P., Committee note to Rule 16. See also Medalie, Federal Rules of Criminal Procedure, 4 LAw. GuILd Rev. no. 3, p. 1, 8 (1944): "The United States Attorney, in a zealous effort to procure all available evidence, not infrequently removes practically every book and paper in the possession of the defendant or his Company via Grand Jury subpoena. If the defendant has not taken the trouble to photostat every book or record, he is frequently helpless in preparing his defense, without an inspection of his books and records."

97. Fed. R. Crim. P. 16. See text, note 21 supra.

98. One problem likely to arise under subsection (c) is that the prosecution will refuse to produce documents on the ground of special privilege. Federal officers are forbidden by statute to produce certain documents. Department of Justice Order No. 3229, filed May 2, 1946, issued pursuant to 5 U.S.C. $\$ 22$ (1946). They have been upheld in refusing to obey subpoenas duces tecum. U.S. ex rel. Touhy v. Ragen, $71 \mathrm{~S}$. Ct. 416 (1951). The same problem has already arisen under the Federal Civil Rules. See Berger \& Krash, Government Immunity From Discovery, 59 YAlE L. J. 1451 (1950).

99. The privilege protects an individual from any incriminating disclosure sought by legal process against him as a witness. This includes the production of documents or other tangible evidence in response to a court order or subpoena. Hence it is unlikely that a statute allowing the state to require the defendant to produce things which he does not intend to introduce in evidence would be upheld against constitutional attack. 8 WigMORE, EVIDENCE $\$$ 2263-4 (3d ed. 1940). 
it subjects disclosure to the court's discretion. ${ }^{100}$ And by requiring the defendant to move for disclosure it forces him to designate the objects he wishes to see. ${ }^{101}$ The designation requirement should involve little hardship: the defendant will usually know about items covered by (a) and (b), and he can get helpful leads to objects he may wish to inspect under (c) by questioning witnesses under Rule 3.

\section{Rule 3: Examination of Witnesses}

Upon the filing of an indictment or information the prosecution shall serve the defendant with a list of the names and addresses of witnesses whom the prosecution intends to call at the trial. ${ }^{102}$ Within fifteen days thereafter (or longer, by leave of the court) ${ }^{103}$ the defendant may give notice of intention to examine any of these witnesses, or any other persons having knowledge material to the case. ${ }^{104}$ The attendance of witnesses may be compelled by subpoena, ${ }^{105}$ and the court may permit the defendant to examine an individual who is in prison. ${ }^{106}$

Examinations may consist of written interrogatories to be answered under oath, ${ }^{\mathbf{1 0 7}}$ or oral questioning under oath with a written deposition to be made of the testimony. ${ }^{108}$ Witnesses may be examined as to any matter, not privileged, relating to the case, including the nature and whereabouts of documents and tangible evidence, or the identity and whereabouts of other witnesses, regardless of whether the testimony would be admissible in evidence. If the examination is oral, the prosecutor may be present and ask questions of the witness.

Thirty days after the last of the above examinations, but, except by leave of the court, no later than ninety days after the defense receives the govern-

100. The discretionary power of the trial court, as provided in FED. R. CRM. P. 16, is criticized in Stewart, op. cit. supra note 62, at 154: "[T] he rule makes the trial judge a court of last resort. If the trial judge refuses to allow inspection, a defendant must wait until he is convicted and then convince the Circuit Court that he complied with all the conditions, and that the Court was wrong in holding that his request was not reasonable. The Circuit Court will say, in effect, that in view of the fact that he was guilty, no amount of preparation could or should have changed the result, so therefore the judgment will be affirmed."

101. FED. R. Crv. P. 34 contains a similar requirement.

102. Compare the witness list statutes, note 41 supra.

103. In some cases it may take more than fifteen days for a defendant to secure an attorney.

104. See Fed. R. Crv. P. 26.

105. See id. 45 (d).

106. Occasionally it may be important for a defendant to get the testimony of a confederate in prison. Whether this right should be afforded in a given case is left to the court's discretion, because of the difficulty of bringing individuals from prison to testify.

107. See id. 31.

108. See id. 30, 28. 
ment's list of witnesses, ${ }^{100}$ and no later than five days before commencement of trial, the defendant shall serve the prosecutor with a list of the names and addresses of witnesses whom the defendant intends to call at the trial. Thereafter the government may conduct examinations in the manner provided above. Any person may be examined, whether or not listed by the defense. Both defense counsel and counsel for the witness may be present and may ask questions, if the examination is oral.

The court shall have power to compel witnesses to answer questions as to any matter not privileged, and relevant to the issues of the case. ${ }^{110}$ No witness may be examined a second time except by leave of the court. The court may limit examinations to prevent harassment, and may prohibit oral examination if it finds the witness is in danger of undue coercion by the opposing side. If the defendant is impecunious, the government shall pay the costs of all examinations. ${ }^{111}$

Depositions may be used at trial, to the extent permitted by the rules of evidence, (a) to prove the truth of the matter asserted, and (b) to impeach.112

If a party, after serving its list of witnesses, decides to call an additional witness, it shall immediately notify all other parties that it is supplementing its list of witnesses. Thereupon such witnesses may be examined in the manner provided above.

No witness shall testify at the trial unless he is previously listed by the party calling him, or unless the court finds that the party did not previously know the witness' whereabouts or the materiality of his testimony. ${ }^{113}$ If an unlisted witness is allowed to testify, the opposing party shall be entitled to a continuance during which it may examine the witness out of court in the manner provided above.

Comment. This Rule provides rights previously unknown to criminal procedure in the United States. It enables the defendant for the first time to discover all that the prosecution's witnesses will say. Inspection of grand jury minutes, where available, gives access only to a portion of this testimony. Witness list statutes give even less, since the defendant, while he can interview listed witnesses, cannot compel them to "talk." At the same time, this Rule enables the prosecution to get warning of possible surprise defenses like alibi and insanity. Even under state alibi statutes, disclosure of the names of defense

109. Without this provision, a defendant with substantial funds could use deposition machinery to postpone the trial unduly. In civil cases this power is sometimes used to force the opponent into a compromise. See Comment, 59 YalE L.J. 117, 131-4 (1949).

110. See FED. R. Crv. P. 37.

111. The problem of expenses may be a serious one if many depositions are involved. See Comment, 59 YALE L.J. 117, 126-31 (1949).

112. Generally depositions may be used to prove the truth of the matter asserted only if the witness is "unavailable." Definitions of unavailability vary, and it might be desirable to adopt the liberal provisions of FED. R. Crv. P. 26(d) in this respect.

113. Compare the witness list statutes, note 41 supra. 
witnesses is seldom required. ${ }^{114}$ Alibi statutes, moreover, are really rules of pleading, likely to work a hardship on defendants who inadvertently fail to give notice of their affirmative defenses. The present Rule involves no such problem. There are no restrictions on a witness' testimony at the trial. He may, however, be impeached if he contradicts his deposition.

This Rule would help to place the parties on an equal footing in their opportunity to prepare for trial. Under present law the prosecution can question any potential witness under oath by calling him before a grand jury.115 If the testimony is unfavorable, the witness need not be called. The defendant, on the other hand, has no way of compelling possible defense witnesses to answer questions before trial; he may have to risk calling them at the trial in the hope that their testimony will help him. In addition, the rule goes far toward preventing intimidation of prospective witnesses. Where the defense, or even the prosecution-when proceeding without a grand jury-questions witnesses extrajudicially, intimidation of witnesses is far more likely than when they are interviewed in the presence of counsel for both sides.

The main difference between this Rule and the comparable Civil Rule lies in the time gap between prosecution and defense disclosure. ${ }^{116}$ Presumably the state will have assembled its witnesses by the time it obtains an indictment. But the defendant will often need time to recruit rebuttal witnesses. If compelled to disclose his witnesses upon the filing of the indictment, he may be unable to comply, with the result that the state would be entitled to repeated continuances as defense witnesses are brought on at the trial.

The Rule is subject to a few limitations. First, witnesses may be compelled to answer only relevant questions; otherwise examinations might stray too far, causing delay, inconvenience, and perhaps personal embarrassment. Second, the defendant may not be examined, because of his privilege against becoming a witness. Finally, the court is given general supervision over the whole procedure to prevent abuses. ${ }^{117}$

\section{Rule 4: Physical and Mental Examinations}

In any case where the physical or mental condition of an individual is in issue, either party may ask the court for an order permitting a physician or psychiatrist to conduct an examination of such individual. ${ }^{118}$ The court shall

114. See notes 47 and 48 supra.

115. See Dession \& Cohen, The Inquisitorial Functions of Grand Juries, 41 YaLE L.J. 687 (1932).

116. No time gap exists in the Civil Rules. See Fed. R. CTv. P. 26(a).

117. See id. 30(b) and 30(d).

118. A number of states have statutes permitting or requiring the court to order the mental examination of defendants who plead the defense of insanity. E.g., CoLo. Stat. ANN. c. $48 \$ 508$ (1935) (where defendant pleads insanity, court must commit him to a state mental hospital for observation; court may also appoint physicians to examine defendant, and they may be called as witnesses by the court or by either party); OHIO GEN. CoDE $\$ 13441-4$ (Page 1937) (where insanity is set up as a defense, court has power 
grant the order if good cause is shown, and may prescribe the conditions under which the examination shall take place. ${ }^{119}$

Comment. This Rule provides a new type of discovery which may be of crucial importance where the physical condition of a prosecution witness is in issue. It may also enable the defense to discover a witness' mental disorder which may throw serious doubt on his capacity to tell the truth. ${ }^{120}$ Rape prosecutions illustrate both functions of the rule. Physical tests may disclose that the prosecutrix was in fact never raped, while psychiatric examination may divulge a mental disorder and provide a basis for an attack on her credibility. ${ }^{121}$

Witnesses are protected from unwarranted examination by court supervision.

\section{Rule 5: Pre-Trial Conferences}

At the suggestion of either party, or on his own initiative, the trial judge may invite the prosecuting and defense attorneys to a pre-trial conference. ${ }^{122}$ This conference shall take place preferably after each side has completed its examination of opposing witnesses under Rule 3.123 At the conference the judge may seek to obtain agreement on the simplification of issues and proof, limitation of the number of expert witnesses, or other matters which will promote a fair and expeditious trial. The judge may embody the results of agreements in an order which shall be binding on the parties at the trial. Neither the judge nor the prosecutor shall at such conference seek or obtain any admissions of guilt from the defendant or a plea of guilty to a lesser offense.

to commit the defendant to a mental hospital for observation and may appoint physicians to examine him; these physicians may be called as witnesses by the court). See Weihofen, Eliminating the Battle of Experts in Criminal Insanity Cases, 48 Mrch. L. REv. 961, 965-74 (1950).

It has been generally held that to compel a defendant who pleads insanity to submit to a mental examination does not violate the privilege against self-incrimination. Ingles v. People, 92 Colo. 518, 22 P. 2d 1109 (1933) ; Noelke v. State, 214 Ind. 427, 15 N.E. 2d 950 (1938) ; Jessner v. State, 202 Wis. 184, 231 N.W. 634 (1930). In People v. Esposito, 287 N.Y. 389, 39 N.E. 2d 925 (1942), use of drugs to facilitate a compulsory psychiatric examination was held not to violate the privilege, but the court did not pass upon the question whether the psychiatrists could have testified to admissions of guilt that might possibly have been made by the defendant while drugged.

119. See FEd. R. Crv. P. 35.

120. See Comment, Psychiatric Evaluation of the Mentally Abnormal Witness, 59 YALE L.J. 1324 (1950).

121. See, e.g., State v. Driver, 88 W. Va. 479, 107 S.E. 189 (1921). And see 3 WIGMIORE, EvIDENCE \$\$ 924a, 934a (3d ed. 1940).

122. See FEd. R. CIV. P. 16.

123. "The testimony of [federal] district judges is overwhelming that the best time for [civil] pre-trial is shortly before trial and this means not less than one week and not more than three as an objective to be attained where possible. The reason for this is that by that time the deadline is close enough so that the parties come into pre-trial knowing what they are going to prove, what the issues are, what documents are to be introduced. ..." Shafroth, Pre-Trial Techniques of Federal Judges, 4 F.R.D. 183, 185 (1946). 
No incriminating admissions made by the defense at the conference shall bind the defendant at trial or be admissible in evidence. Pre-trial conferences shall not be held unless the defendant is represented by counsel.124

Comment. Pre-trial conferences make possible the simplification of complex cases through the use of knowledge gained by disclosure. ${ }^{125}$ Experimentation with such conferences in antitrust prosecutions and other involved criminal cases suggests that pre-trial may prove valuable in the criminal field if coordinated with disclosure procedures. ${ }^{226}$ The function of pre-trial is, however, more limited in criminal than in civil cases. Aside from simplifying issues, an additional purpose of civil pre-trial is to encourage compromise. But in a criminal case, where the public interest is at stake, compromise is not an appropriate aim of judicial processes. For this reason, the Rule forbids the judge or prosecutor to obtain from the defendant admissions of guilt or pleas of guilty to lesser offenses.

\section{Conclusion}

The foregoing Rules should be a long-range objective of American criminal procedure. The disappearance of private prosecution and the new attitude toward criminals as products rather than enemies of society make increasingly inappropriate a combat-type trial. And the accurate fact-finding which the Rules would promote is even more vital in criminal than in civil cases. Injustices resulting from mistakes of fact are not only tragedies to the persons accused; they may undermine confidence in government itself. Therefore imposition of criminal sanctions should be based on procedures best designed to find facts accurately. Elimination of secrecy and surprise from criminal trials would be a significant step in this direction.

124. See Federal Rules of Criminal Procedure, Second Preliminary Draft 78 (1944).

125. For an attack on the use of pre-trial in criminal cases, see Fee, supra note 69 , at 340-1. On the successful use of pre-trial in civil cases, see NIMS, PRE-TrIaL (1950). The use of pre-trial in civil antitrust cases is discussed in detail in McAllister, The Big Case: Procedural Problems in Antitrust Litigation, 64 Harv. L. Rev. 27 (1950).

126. See Way, Nere Technique Facilitates Criminal Trials, 25 J. AM. Jud. Soc'y. 120 (1941). The tentative drafts of the Federal Criminal Rules included a pre-trial provision, but it was rejected by the Supreme Court on objections from government and defense lawyers. Dession, The New Federal Rules of Criminal Procedure, 56 Y ALE L.J. 197, 215 (1947).

On the possible dangers of pre-trial, see Fee, supra note 69, at 3-2-7; Shafroth, supra note 123 . 